\title{
COMMUNITY-MANAGED WATER SERVICES: THE CASE OF PERU*
}

Joan Calzada, Universitat de Barcelona: calzada@ub.edu

Susana Iranzo, Universitat Rovira i Virgili: susana.iranzo@urv.cat Alex Sanz, Universitat Autonoma de Barcelona: Alex.Sanz@uab.cat

\begin{abstract}
Due to lack of economic resources and the geographical dispersion of the population, state and private for-profit water provision is not feasible in many remote rural areas of developing countries. In such instances, community-managed water systems emerge as an alternative mechanism to provide safe water. Despite their importance, little is known about this type of organizations. This paper examines the Juntas Administradoras de Servicios de Saneamiento (JASS), communal organizations that provide water services to more than 3 million people in rural and peri-urban areas of Peru. We focus on two important and related dimensions of the JASS. First, we empirically identify the factors associated to their existence in rural areas (economic resources of the municipalities, tradition of communal work, ethnic homogeneity). And second, we examine their organization and how they manage the water systems, which is importantly affected by the socio-economic characteristics of the communities. Using the Peruvian JASS as a showcase, this paper sheds then some light on the potential viability of this type of organizations. We conclude that the JASS might be an important and effective alternative to organize the provision of water services in rural and isolated areas. However, the consolidation of these institutions requires adequate supervision to ensure that water systems are correctly designed and managed, and that internal governance problems do not compromise their sustainability.
\end{abstract}

Keywords: Water, community planning, JASS, governance, rural areas, Peru. JEL: D83, D85, L12, L22, L86, M31

\footnotetext{
* For the preparation of this paper we have received the help from several Peruvian public agencies and communal organizations. We especially acknowledge the comments and suggestions of two anonymous referees, Roger Agüero, Antonio Estache, Joan Ramon Borrell, Juan Luis Jiménez, Fernando Laca, Jessica Oliva and Victor Sevilla. Calzada acknowledges financial support from the Spanish Ministry of Economics and Competitiveness (ECO2015-69193-R) and Iranzo from the Spanish Ministry of Economics and Competitiveness (ECO2016-75410-P).
} 


\section{INTRODUCTION}

The relevance of water for human development and the pressing need to reduce water-related diseases were clearly highlighted in the United Nations Millennium Declaration of 2000. Since then, most developing countries have taken important steps to increase access to safe drinking water. For instance, in Latin America and the Caribbean alone, the rate of access to drinking water increased from around $85 \%$ in 1990 to $94.6 \%$ in $2015 .{ }^{1}$ However, these rates are not homogeneous within the Latin America and Caribbean region. In rural areas access to water stays at $83.9 \%$ while access to piped water stands at just $67.9 \%$. In the case of Peru, in 2015 only $69.2 \%$ of the rural population had access to water and just $48.1 \%$ had access to piped water.

In most countries, access to basic utility services such as water or energy is guaranteed by the state which has traditionally provided them. On the one hand, the state can obtain the resources needed to finance the services and has the coercive power to enforce their regulation. Moreover, the provision of basic services is considered to give legitimacy to the state. On the other hand, the natural monopoly problem has provided an economic justification for the provision of these services by the public sector. ${ }^{2}$ Yet, in many rural and remote areas of developing countries the state fails to deliver these essential services at minimum quality levels and affordable prices. Some of the difficulties that hinder the public provision of water are the lack of economic resources and the poverty of the population living in these areas, as well as the inefficiency of public systems. Several strategies have been pursued to remedy this situation including privatization, market liberalization or the use of intermediate solutions such as public-private partnerships, and a number of academic papers have analyzed the impact of such policies in different countries (McKenzie and Mookherjee ,2003; Gassner et al., 2008; Clarke et al., 2009; and Tan, 2012). However, one critical aspect the literature has overlooked is that in many rural areas of developing countries where local governments fail to provide the service, private provision is unlikely to be an alternative because it would be unprofitable. In these instances, citizens might have no choice but to turn to their communities for the self-delivery of services and create organizations to that aim (Alesina and Zhuravskaya, 2011). As the literature on collective action and co-production has shown, citizens can play an active role in managing public services in poor and unattended areas of developing countries, but building social capital for effective cooperation and coordination is a difficult task (Ostrom, 1996). In this paper we focus on communities in rural areas of Peru that use communal organizations to provide water services. We examine the factors explaining the creation of these organizations and the governance problems they face.

Communal organizations are civil associations of users that run the water service. These organizations are quite prevalent in Latin America. It is estimated that more than 77,000 of such organizations provide water to around 40 million people. They are particularly important in the Andean countries where the tradition of communal work can be traced back to the ancient culture of cooperation of the pre-Columbian Maya and Inca civilizations, known as Kuchuj and Minka, respectively. In Ecuador there are around 7,000 Juntas Comunales and Juntas de Administración de Agua Potable serving 2.7 million people, that is, $20 \%$ of the total population (PROTOS-CEDIR, 2011). In Colombia, in the 2000s, several public programs promoted the creation of Juntas Administradoras and Asociaciones de Usuarios and, today, there are around 16,000 communal organizations (Smits et al., 2012; and LlanoArias, 2015). In Venezuela, in 2002 the government created the Mesas Técnicas de Agua, and 
by 2014 they were around 9,000 Mesas providing water services to more than 900,000 people in indigenous, rural communities (McMillan et al. 2014; Llanos-Arias, 2015). In rural and peri-urban areas of Bolivia, there are around 4,500 Comités de Agua Potable y Saneamiento (PROTOS-CEDIR, 2011).

This paper analyzes the Peruvian Juntas Administradoras de Servicios de Saneamiento (JASS), which are community-managed organizations that provide water services to more than 3 million people in rural and peri-urban communities in Peru. The analysis of these organizations is particularly interesting as many Peruvian communities adhere to the longstanding tradition of communal work that has survived in the Andean region, and because Peru is the only country in Latin America where the legislation has explicitly established that water services in all rural communities might be delivered by communal organizations.

The JASS are independent, non-for-profit civil associations that build and manage water systems, and so they are markedly different from public and private organizations. The households that are members of these associations are simultaneously owners of the water infrastructures and users of the service. As owners, they run the water systems and have to dedicate a number of hours every year to their construction and maintenance. As users, they get access to the water services and have to pay a monthly fee. The governing structure of the JASS includes a general assembly, a management board and a supervisory board. The assembly comprises all the members of the JASS and is responsible for democratically choosing the management board, approving the work plan, the annual budget, and the household fees. The board designs the projects, plans the tasks of each member, and supervises the provision of water services. In the last years, several laws have affected in one way or another the functioning of the JASS, but it was not until 2010 that they were firstly regulated. This legislation mainly focuses on organizations aspects such as the election of the board and their accountability, but it does not establish any protocol to manage the water systems or to establish the tariff scheme imposed to their members.

Despite their importance, very little is known about the JASS. In this paper we shed some light on the strengths and challenges faced by these organizations. First, we empirically analyze the socio-economic and cultural factors associated with the creation of the JASS in rural communities. And second, we explain in some detail how the JASS manage the water services and describe their major governance challenges. Clearly, the two aspects are very related, because the socio-economic and cultural characteristics that explain the presence of the JASS in some communities also help to explain their governance problems.

We draw on a rich survey undertaken by Peru's National Statistics Institute (INEI) to identify the factors associated to the existence of JASS. We find that households in municipalities with fewer resources and higher poverty rates are more likely to have access to water through a JASS. The JASS are also more likely to emerge in more homogeneous communities from an ethnic and linguistic perspective, and in areas of strong influence of the Inca civilization in which the Minka tradition of communal work has been maintained throughout the years.

Our analysis is complemented with an additional dataset created from a survey conducted recently by the Ministry of Housing, Construction and Sanitation (MVCS). The survey includes further aspects of communal organizations which are not typically accounted for in standard statistics. Based on this data, we can document relatively high coverage rates of the 
JASS, which is important given the limitations faced by these organizations. Several drawbacks affecting the JASS can also be identified such as the lack of accountability of their boards, the scarce support and resources they receive from public administrations, the difficulties to collect the billed water, or the insufficient chlorination of the water. This raises the concern about the sustainability of the water systems, not only as far as their performance is concerned, but also regarding broader aspects such as the provision of the service over time, its environmental impact, the role of the members of the community in the operation of the service and the effects on equity in the community. ${ }^{3}$ Based on this, it is our belief that communal organizations require a more intense supervision and support of the public authorities in order to guarantee a quality service and to improve social capital.

The rest of the paper is structured as follows. Section 2 reviews the literature on communitymanaged projects and the delivery of basic services in developing countries. Section 3 briefly explains the organization of the water sector in Peru and describes the functioning of the JASS. Section 4 empirically analyzes the factors associated with the presence of JASS in Peruvian municipalities while Section 5 identifies the main operational and governance problems they face. Finally, Section 6 concludes.

\section{CONCEPTUAL FRAMEWORK: COMMUNAL ORGANIZATIONS AND THE DELIVERY OF COLLECTIVE SERVICES}

Communal organizations have been analyzed by different fields. In the literature on public administration, collective production of services is referred to as co-production and it is considered an alternative to public provision (Pestoff, 2006; Alford, 2014; and Sicilia et al., 2015). ${ }^{4}$ According to Ostrom (2004), although co-production is usually associated with activities carried out by formal organizations, more attention should be devoted to informal production, where local communities organize and coordinate the provision of basic services. Following this view, in the last years several studies have analyzed the factors that motivate co-production, how it is organized, and how it can be improved.

In developing countries, the members of rural communities can cooperate with each other and with public institutions to ensure access to basic services that they would probably not receive otherwise. Joshi and Moore (2004) identify two types of motivations for coproduction: governance drivers, when there is a decline in the governance capacity of a public administration to deliver a service, and logistical drivers, when services cannot be effectively delivered by state agencies because of environmental complexity and high costs. Both motivations help explain the participation of the community members in the design and the operation of water systems in some areas of developing countries, with the ultimate objective of guaranteeing the existence and sustainability of the services.

The literature on co-production has also sought to determine the organizational structures that facilitate collaboration between community members. In her analysis of the provision of water and sanitation works in urban and peri-urban areas of Brazil, Ostrom's (1996) identified several conditions to ensure co-production: defining the boundaries of the resource itself as well as those of the group of users, adapting the rules concerning use and provisions to local circumstances, involving co-producers in the decision-making, restricting the involvement of external authorities as to preserve the right of communities to self-organize, and developing a (social) infrastructure for resolving conflicts between actors. Other authors, including Alford (2014), have highlighted the importance of implementing a decentralized 
structure to allow community members to make on-the-spot judgments and solve specific management problems.

The advantages and weaknesses of co-production have been examined in several papers, although most works discuss experiences in developed countries and there is a dearth of empirical studies. Verschuere et al. (2012) argues that co-production leads to better quality service delivery because the greater involvement of users leads to higher levels of satisfaction due to greater "moral ownership" and to the tailoring of services to particular needs. Moreover, co-production of water services can also promote the provision of other public services, such as rural electrification or the maintenance of roads. On the negative side, some authors argue that co-production can strengthen insider/outsider dynamics, with some social groups actively guarding their own interests and discouraging other groups from engaging (Brandsen and Helderman, 2012). Moreover, the system can give rise to issues of equity, since wealthier, better educated and non-minority citizens may be more willing and able to participate in co-production activities (Rosentraub and Sharp, 1981). Our paper adds to this debate by examining the governance problems that affect the JASS in Peru.

An important element of our paper is also the analysis of the factors associated to the creation of communal organizations. In this sense, the literature on collective action in political science and economics has examined the problems associated to the provision of public goods and services and the characteristics of the communities that make their members more likely to self-organize and contribute to the provision of such services (Olson, 1965; Alesina and La Ferrara, 2000). Several theoretical papers have considered the feasibility of cooperative agreements in communities in which there are different interest groups. In these models, every group in the community is better off when all groups adhere to a cooperative agreement than when none does; yet, when every other group cooperates, each group can secure a windfall gain by reducing its effort to secure the common objective, a classic prisoners' dilemma. (Bardhan, 1993). Taking this into account, the empirical literature has analyzed the factors that affect the sustainability of cooperation. For example, some papers have focused on the scarcity of the public good, the cost of providing the service, the size of the community, the existence of past successful experiences with cooperation, the presence of leaders who are willing to act altruistically to create the organization, income inequalities, and the ethnic composition of the community (Meinzen-Dick, 2007; Ostrom, 1990; Gorton et al, 2009). Other important aspects include the cost of deploying the infrastructures, the relevance of the service for the community, existing arrangements for discussion of common problems, punishments against rule breaking, and the Nation State's tolerance of locally based authorities. In section 4 we empirically analyze the characteristics of the local communities conductive to the emergence of JASS, but due to the data limitations, we just focus on their economic conditions and their ethnic and linguistic composition. Several papers have also highlighted the relevance of these aspects. Miguel and Gugerty (2005) analyze the effect of ethnic heterogeneity on school spending in western Kenya, where a significant part of school expenses is financed by parents through collective contributions. Banerjee and Somanathan (2007) found that in India, in the early 1970s, the presence of Brahmans (an elite priestly caste) was positively correlated with access to primary, middle and secondary schools, to post offices and to piped water. Prokopy and Thorsten (2008) examined the determinants of household's participation in rural water-supply projects in the Cuzco Department of Peru. They show how income, wealth, social capital and other household characteristics are associated to meeting attendance and involvement in decision making. Shrestha (2013) analyzes community water supply projects in Nepal and shows that 
communities are more successful in attracting public funds when they enjoy lower internal conflict about the distribution of costs and benefits of the projects (internal social capital) and greater external partnerships (external social capital).

Finally, this paper is also related to the literature on economic development and communitydriven projects. Community-driven projects are those that actively involve their beneficiaries in their design and management and where communities have direct control over key project decisions (Mansuri and Rao, 2004). The development literature has argued that these projects can overcome some of the management difficulties that appear in the provision of public services in rural areas. First, members of the community tend to have a better knowledge of the actual needs and might be more willing to contribute financially to a project if they are entrusted with some degree of decision-making. Based on this belief, the 1990s witnessed a flourishing of community-managed rural water systems supported by various international agencies. Many papers have examined the results of this approach. For instance, Katz and Sara (1997) show that sustainability is associated with the level of participation of the community in the design and management of such water projects. Galiani et al. (2009) examine the role of local communities in the extensions of water facilities to urban shantytowns in Argentina. Bakalian and Wakeman (2009) and Whittington et al. (2009) analyze the sustainability of community-managed rural water supply programs in 400 communities in Bolivia, Ghana and Peru, and find that the projects operated by communal organizations performed remarkably well, although they also identify several governance problems associated with these organizations.

By contrast, other papers are somewhat critical about the effectiveness of community-based and community-driven development initiatives. Mansuri and Rao (2004) argue that these projects may not correctly reflect the preferences of the communities may not create the adequate infrastructures and might not improve welfare outcomes. Another criticism, similar to those pointed out in the literature on co-production, is that community-driven projects might be controlled by community elites and never reach the intended beneficiaries (Platteau, 2004; Dasgupta and Beard, 2007). Rigon (2014) argues that careful management of participatory projects implies tackling powerful interests which in turn requires resources that may not always be available. In these instances, 'participation' may become a tool for saving money by passing on some of the costs to the poor.

\section{THE PERUVIAN WATER SECTOR}

This section briefly explains the organization of the Peruvian water sector and describes the main characteristics of the JASS which constitutes a useful framework for the empirical analysis.

\section{Recent regulatory reforms}

In order to understand the current organization of the water sector in Peru, it is important to know the regulatory changes that the sector underwent during the 1990s and 2000s. The first major set of reforms was implemented in the early 1990s when Alberto Fujimori's government initiated the decentralization of water delivery. In 1994 the government approved a law, Ley General de Servicios de Saneamiento (LGS), which defined the new role to be taken by industry participants and created a national regulator, the Superintendencia Nacional 
de Servicios de Saneamiento (SUNASS). The government also put in place various investment projects, including the Programa Nacional de Agua Potable (PRONAP) whose objective was to expand the coverage of the service to rural areas.

The LGS succeeded in improving the efficiency of urban water operators. It transformed 44 large municipal firms into public companies known as Entidades Prestadoras de Servicios (EPS) that nowadays manage the water and sewerage services in the main urban areas of the municipalities. More importantly, the LGS established that in each municipality "rural population units" (administrative sub-units with less than 2,000 inhabitants) ${ }^{5}$ could be served by communal organizations. As a consequence, these organizations, which for years were operating informally in many municipalities, received legal recognition. Moreover, after this reform many communal organizations were created, although still not regulated. Also in this period the Peruvian government and some international donor organizations initiated several projects to extend the water services to the rural areas. However, most of the projects did not consider the participation of the communities and in many cases the new water systems were never operated or soon deteriorated due to lack of maintenance (Castillo and Vera, 1998; and Calderon, 2004).

The role of communal organizations was further reinforced in the mid-2000s under the reforms of Alejandro Toledo. In 2003, the newly created Ministerio de Vivienda, Construcción y Saneamiento (MVCS) modified the water regulation framework and the Ley Orgánica de Municipalidades (LOM) made it possible for communal organizations, and in particular the so-called Juntas Administradoras de Servicios de Saneamiento (JASS), to be in charge of the construction and operation of the water systems in the rural population units of the municipalities. This reform consolidated the dual provision system that operates in Peru today: in the urban areas of the municipalities the service is mainly delivered by EPS and local governments (public provision) and is regulated by SUNASS, while in the rural population units the service tends to be operated by the JASS (communal provision) and supervised by the local and regional authorities.

More precisely, the provision of water across urban and rural population units is as follows. In urban population units, there are 54 EPS supplying the service to around $60 \%$ of the country's population, whereas local governments provide the service in more than 220 small cities not covered by EPS, representing $9 \%$ of the country's population. Private provision, which was introduced in 2005 , covers a very small percentage of the population and is confined to some urban areas in the Department of Tumbes because popular opposition prevented it from extending to other regions. The rest of households in urban population units gets access to water through communal organizations, and there is a small percentage of households that obtains water from private wells or from small scale local operators that supply water via tankers, barrels, or small networks (Felgendreher and Lehmann, 2016; Ringskog et al., 2007; and Israel 2007).

In the rural population units, the JASS provide water services to approximately $85 \%$ of the population. There are also several rural population units where the service is delivered by local governments and in other cases the provision of the service is not formally organized and the population obtains water from wells, streams, the rain or other unorganized alternatives (Calderon, 2004). 


\section{The JASS}

The JASS are civil associations whose members are simultaneously owners of the water infrastructures and users of the service. As owners, they run the water service and contribute with their work to the construction and maintenance of the facilities. As users, they get access to the water service for which each household needs to pay a monthly fee set by the JASS.

It is interesting to note that these communal organizations find their historical roots in a preColumbian tradition of communal work called Minka. Before the arrival of the Spaniards in Peru, the Incas used communal work to build roads and public buildings, as well as to undertake various farming tasks. This tradition has been maintained in several areas of Peru, particularly those with high presence of Quechuas, the descendants of the Incas. As we later discuss, the existence of this tradition can have important consequences for the creation of the social capital necessary to induce the involvement of the community members of the community in the activities of the JASS (Ostrom, 1996, 2004).

The legal structure of the JASS includes a general delegate assembly, a management board and a supervisory board. The assembly comprises all the members of the JASS and is responsible for appointing the management board, approving the work plan, the annual budget, and the household fees. As members of the JASS, households have the right to access the water service as well as to participate in the assembly and be eligible to sit on the management and supervisory boards. The management board is democratically chosen by the assembly and is responsible for defining projects, planning activities and supervising the provision of water services.

From a managerial perspective, the success of the JASS depends on a number of factors, from the involvement of the members of the organization, to their technical knowledge of how to run the service and maintain the infrastructures (e.g., how to correctly carry out the chlorination of the water and the disinfection of the reservoirs and pipelines), and the actions they adopt to guarantee the economic sustainability of the projects (e.g., fee setting and fee collection). We get into more detail on these key issues in Section 5 where some of the governance and operational problems of the JASS are analyzed.

The JASS might obtain support from national institutions and international donor agencies, which have an essential role in helping them to overcome technical problems associated with the management of the service, and financial difficulties. Most of the support offered to the JASS has been channeled through investment institutions. In 2003, the MVCS created the Programa Nacional de Agua y Saneamiento (PRONASAR), a program that funded and coordinated the creation and rehabilitation of water systems. Local communities were asked to propose projects to PRONASAR, which were then selected based on criteria of efficiency, equity and the needs of the communities. An essential characteristic of PRONASAR was that it promoted the participation of rural organizations and local governments in the design and development of the projects. It also gave training and technical assistance to the JASS.

In 2012 the Programa Nacional de Saneamiento Rural (PNSR) replaced PRONASAR. PNSR's main objective is to increase access to water and sewerage services for the population living in rural areas, giving priority to the communities of more than 500 inhabitants with high needs. In the beneficiary communities, all households are offered an 
indoor water connection, a toilet, and sewerage services. The PNSR implements the so-called Project Cycle which involves a three-stage process. First, the PNSR hires external consultants to verify that local communities satisfy the program's prioritizing criteria. Moreover, it promotes the creation of Areas Tecnicas Municipales (ATM), which are administrative units in the municipalities that offer support to the JASS. On the other hand, local communities are required to create (or reactivate) a JASS, open a census of potential users, and must also choose the most appropriate design for the water systems according to the characteristics and needs of the communities. Second, the PNSR creates the infrastructure and gives training to the members of the JASS that will maintain and run the water system. It also offers courses on sanitary education to the community. Finally, after the construction stage, the PNSR transfers the infrastructure to the JASS and for some additional months gives support to the local ATM and the JASS.

\section{EXPLAINING THE PRESENCE OF THE JASS IN LOCAL COMMUNITIES}

Communal organizations have been present in rural and peri-urban areas of Peru for decades, but they were only granted legal recognition in the 1994 Ley General de Servicios de Saneamiento (LGS) and their role was reinforced in the 2000s with the 2003 Ley Orgánica de Municipalidades (LOM). The LOM urged local authorities to promote the creation of the JASS and to supervise them. In recent years, many informal communal organizations have been legalized, and new JASS have been created. Yet, hundreds of rural communities remain without a water provider and many others are served by local governments. This raises the question as to which factors, apart from the legal dispositions that encourage communal provision in the rural population units, favor the creation of the JASS. Knowing the factors conductive to the emergence of JASS can provide important insights to understand the governance challenges they might be subject to. For example, if JASS are more likely in poorer communities, they are also likely to experience problems of under-payment of fees, or non-payment, which in turn would compromise their financial sustainability.

In this section we carry out some empirical analysis to help explain the existence of the JASS in Peruvian municipalities. Our goal is not to establish a causal relationship but just to identify the factors associated to the JASS. First, we discuss the set of potential explanatory factors, then describe the data sources and finally show the empirical results.

\section{Potential explanatory variables}

There are three types of factors that might be important to explain the presence of JASS in a municipality: the difficulties of local governments to provide the water service, the community's internal social capital and the level of homogeneity of the community. We discuss next the proxy variables used for each one of these groups of factors as well as their expected relation with the existence of JASS.

Our first conjecture is that the presence of a JASS in a municipality is related to the financial and technical difficulties of local governments to set up and manage the water service themselves. Local governments in rural areas provide the service in the capital of the municipalities, but for decades they have lacked the financial resources and the personnel to extend the service outside the center of the municipality. Felgendreher and Lehmann (2016) argue that in some cases this situation can be explained by the reluctance of local politicians 
to increase water fees due to their potential effects on votes. This might be a more severe problem in poor and low-income municipalities. Taking this into account, we would expect the JASS to be more prevalent in municipalities where local governments have less fiscal resources and where there is a larger percentage of households under the poverty line. We use the municipality's per capita fiscal revenues and the per capita professional personnel to proxy for the financial and technical difficulties of local governments, and also the municipality's altitude to proxy for the topographical characteristics that could make the construction of pipeline networks more challenging.

Our second set of explanatory variables includes factors that contribute to the internal social capital of communities. One of them is the Minka, the tradition of communal work dating back to the Inca civilization that is still present in many Andean communities. Our conjecture is that the JASS should be more likely in areas where the Inca influence is more intense. We use two variables to proxy for the Minka tradition: the percentage of Quechuas in the municipality and a variable reflecting the geographical areas under Inca rule. The Inca Empire emerged in the Andean region in the $15^{\text {th }}$ and $16^{\text {th }}$ centuries. Its geographical expansion began in the Cusco region around 1438, and continued until 1534 when the Spanish troops of Francisco Pizarro entered Cusco and completed the conquest of Peru (Espinoza, 1997). As descendants of the Incas, the ethnic group of Quechuas can be considered the recipients of the Minka tradition, which indeed they have kept throughout the years. Taking into account that the Inca Empire occupied most of the Sierra and the Coast of Peru but did not expand to the Selva region, we exploit the geographical variation in the Inca settlements to test for the influence of the Minka tradition on the presence of JASS. A different type of social capital we consider is the existence of cabildos, a very prevalent institution in Peru that promotes the participation of the local population in the decisions of the municipality. Specifically, the cabildos are meetings that the majors of municipalities organize in which they obtain information about the opinions and the needs of the citizens. We believe that dynamic and participative communities that regularly use this type of platforms to discuss about collective problems could be more prone to create a JASS.

Finally, our third type of explanatory variables is related to the literature on collective action (discussed in Section 2 above) that argues that the creation and viability of communal organizations are more likely in more homogeneous communities. To test this hypothesis, we examine whether communities that are more homogeneous from an ethnic and linguistic point of view are also more likely to have a JASS.

\section{Data and methods}

Our study draws from the Encuesta Demográfica y de Salud Familiar (the ENDES survey) which is a detailed, nationally representative survey conducted at the household level by the Peruvian Statistics Institute. We complete this information with data from the Peruvian Census and other sources reported below. Our dataset includes observations of over 21,000 households throughout Peru surveyed in 2010. Table 1 shows some descriptive statistics of the variables. Almost $42 \%$ of the households reported obtaining the water from a JASS, 52\% from a public firm, $3.6 \%$ from a private operator (only in the region of Tumbes), and $2 \%$ from another type of private firm. Given that private provision accounts for a very small percentage of households and it is mainly confined to one administrative region of Peru we 
eliminate those observations and restrict the attention to the choice between water provision by a JASS or a public system.

We take full advantage of the disaggregated nature of the data and estimate the following probit model on the probability of a household accessing water through a JASS: ${ }^{6}$

$$
\operatorname{Pr}\left(\text { Communal Provision }_{\mathrm{h}}=1 \mid \mathrm{X}\right)=\alpha+X_{\mathrm{m}} \cdot \beta+\delta_{\mathrm{r}}+\varepsilon_{\mathrm{h}}
$$

where $h$ is the household and $m$ indexes the municipality. The variable Communal Provision is a binary variable that takes value 1 if the household obtains water from a JASS and 0 if it obtains it from a public system. The probability of a household being served by a JASS is explained by the vector $X_{\mathrm{m}}$ of explanatory variables discussed above, namely the proxies for economic and technical resources of the municipality, proxies for the influence of the Minka tradition and the existence of a cabildo, and the municipality linguistic concentration. All the regression models also include the population of the municipality (in logarithms) as it is an important variable to control for and region fixed effects $\left(\delta_{\mathrm{r}}\right)$ to account for unobserved heterogeneity across the 26 Peruvian administrative regions. We also use individual household controls in the main specifications. Finally, $\varepsilon_{\mathrm{m}}$ is the error term.

\section{Results and discussion}

Table 2 reports the estimation results of several specifications of the model lay out above. Model I includes the first set of explanatory variables, those related to the financial and technical resources of municipalities. We find that households in less populated municipalities are more likely to access water through a JASS, and this result is consistent across all models. The JASS are also more likely in municipalities with less technical and specialized personnel as proxied by the variable Professional Personnel per capita. This variable reflects the number of employees in the local government classified as either professional or technical, and was obtained from the National Registry of Municipalities (RENAMU). By contrast, the per capita Revenues of the local government do not seem to matter (i.e., it is not statistically significant) in the choice between communal and public provision.

Model I also includes the variable Poverty Index, which shows the percentage of the population in the municipality below the poverty level. The information for this variable was obtained from the Ministry of Development and Social Inclusion (MEDIS). The index is created taking into account several aspects such as the households' income, the employment in the agricultural sector, the lack of basic services such as water, sewerage and electricity, and the characteristics of the houses (MIDIS, 2012). ${ }^{7}$ The estimate for this variable implies that households in poorer municipalities are more likely to access water through a JASS.

Finally, in order to capture the costs of remoteness that also limit the ability to set up public water services we include in model I the altitude of the municipality in meters (Altitude) which does not seem to matter to explain the type of water provision.

On model II of Table 2, we add the set of explanatory variables that contributes to build up community social capital. We would expect the JASS to be more prevalent among municipalities that have institutions that rely on communal participation. To test the importance of the Minka tradition, we create the dummy variable Inca, which takes value 1 if the municipality lies within the area that was under Inca rule and 0 otherwise. As observed on 
model II, municipalities in historical Inca settlements are more likely to have a JASS. We also use the share of the Quechua population in the municipality (variable Quechua). Although the Quechua culture has evolved in different directions across the Peruvian territory and includes several sociolinguistic variants, we interpret this variable as a measure of the intensity of the Minka tradition. The estimates of both variables indicate that the JASS are more likely in municipalities with a stronger Inca influence. The second communal institution we consider is the existence of a cabildo in the municipality. Based on the estimate of the variable Cabildo we cannot conclude that this discussion platform has a significant correlation with the existence of the JASS. One possible explanation for this finding is that the cabildos are not a good instrument to measure the capacity of rural communities to organize the provision of basic services. On the other hand, it is also possible that the communities that have this institution are more successful in obtaining the basic services provided by the municipality.

On model III we explore the hypothesis put forward by the collective action literature and test whether the linguistic homogeneity of Peruvian municipalities makes provision by a JASS more likely. Besides Spanish (the most commonly used language in the country), there are several other native languages spoken in Peru, including Quechua (the most used among the indigenous languages), Aymara and Ashaninka. The Census of Peru provides information on the languages spoken in each municipality. We computed the Herfindahl-Hirschmann index to measure the linguistic concentration in each municipality. The results on model III of Table 2 suggest that linguistic homogeneity (proxied by the Linguistic Homogeneity Index) is associated with communal provision although this relation is not statistically significant.

Individual household variables are added in model IV to check the robustness of the results to the inclusion of further controls. In particular, we include the educational level and ethnicity of the person interviewed in the household, an income index and household assets such as having electricity, a TV, a fridge and a vehicle that serve as additional indicators on the income and consumption levels of the household. Qualitatively the results are the same. The only differences are that the relations between communal provision and the municipality per capita personnel and between communal provision and the percentage of Quechuas do not appear to be too robust as they are not statistically significant now. ${ }^{8}$ On the other hand, the effect of linguistic homogeneity is now reinforced, what confirms that the JASS are more likely among communities that are more homogeneous from a linguistic perspective.

Finally, on model $\mathrm{V}$ we eliminate the observations from those municipalities with less than 2,000 inhabitants, as they are likely to have more rural units in which JASS are encouraged to operate by the Peruvian legislation. By and large, the results carry through when we restrict attention to this sub-sample.

To sum up, the empirical analysis conducted in this section shows that the JASS are more prevalent in municipalities where local governments have fewer resources and where an important part of the population lives under the poverty line. These findings confirm the idea that the JASS are the default provision system in rural and poor communities which in turn has important implications with regard to the financial sustainability and governance issues of these organizations. We also find that the JASS are more likely to emerge in communities that are relatively homogeneous from an ethnic and linguistic perspective, and that are influenced by the Minka tradition of communal work. This is also an important finding from 
a policy viewpoint. It suggests that culture and institutions might not only play an important role on the emergence of this type of organizations but also on their success.

\section{ANALYSIS OF THE MAIN OPERATIONAL AND GOVERNANCE ISSUES OF THE JASS}

After the legislative changes introduced in the 2000s, the JASS gained importance in the provision of water services in the rural population units of the Peruvian municipalities. They are responsible for managing the water systems, maintaining the infrastructure, setting household fees and sanctioning the users that do not meet their obligations. This section identifies the main governance problems of these organizations that are key to ensure their sustainability.

\section{Governance of the JASS}

In 2010, the Peruvian government passed new legislations that regulated the internal functioning of the JASS (Resolución Ministerial No 205-2010-Vivienda and No 207-2010Vivienda). Its main purpose was to establish the process by which the representatives of a JASS are to be elected and renewed and to guarantee their transparency and accountability. The institutional structure of the JASS consists of a general delegate assembly, a management board and a supervisory board, the latter having power of veto over the management board. The assembly comprises of all the members of the JASS and is responsible for approving the statutes and rules of the organization and appointing the management board. Each year it must approve the work plan, the annual budget, and the household fees. The management board comprises of at least five representatives (President, Secretary, Treasurer, and two additional posts) and oversees the management of the water system. The board proposes the household fees, bills the water, collects the payments, establishes a penalty system, and draws up the annual budget and the work plan. As for the infrastructure, it supervises the installation of household connections, sewerage and toilets.

A survey on JASS operating in rural communities (Encuesta de Diagnostico sobre Abastecimiento de Agua y Saneamiento en el Ámbito Rural) was conducted in 2015 by the PNSR. Although the survey does not cover the universe of JASS (the country has more than 85.000 rural communities), it has information on 10,700 organizations from which we can obtain a highly-detailed picture of their operations and characteristics. Table 3 offers some descriptive statistics about the communities that answered the survey. We present the information for the full sample of communities, for each of the geographical regions of the country (Costa, Sierra and Selva), and for the administrative region of Lima (that includes the capital of the country, Lima). As observed, the average number of persons living in rural communities attended by a JASS is 428 , a number slightly higher in the Sierra and the Selva regions. In these communities, the average coverage of improved water is $70.5 \%$ (or 81 households) and the average coverage of improved sewerage is $46.6 \%$ (or 54 households). This coverage is considerably lower than in the urban areas of Peru, but it is important to bear in mind that these communities rely on self-provision.

Table 4 presents several governance indicators about the JASS. More than $90 \%$ of the organizations elected their board in the last two years and they celebrate meetings periodically (on average, they meet every two months). Although most JASS elect 
democratically their representatives, the boards present several deficiencies: half of them were not registered in the local governments, around 56\% did not have women serving on the board, $19.8 \%$ had not met in the last 6 months, and only $26.3 \%$ reported the results of the JASS to the general assembly. Moreover, only $37.5 \%$ of the boards kept accounting records, which clearly affects their accountability in front of the assembly. Anecdotal evidence also raises the concern that in small communities the board may be dominated by a few families and there is insufficient renewal of members in the governance bodies (Prokopy and Thorsten, 2008). The literature on collective action has shown that the design and governance of communal projects is particularly vulnerable to elite capture because members of the organizations enter the process from unequal positions of power: they have asymmetrical social positions, different access to economic resources, varying levels of educations and knowledge, and different types of connections with political institutions. Taking this into account, several papers have shown how their presence may affect the involvement of the members of the communities in the projects and on the sustainability of the institutions (Dasgupta and Beard, 2007; Palmer, 2014; Hansen et al. 2015; and Tafon and Saunders, 2015).

Another important aspect of the JASS is their autonomy from local and regional governments. For many years, they went virtually unnoticed by the Peruvian government, and only in the last decades has the government recognized their existence and regulated them. In the last decades several, JASS have received external training and funding for water infrastructures, especially those participating in programs like PRONASAR or PNSR, but many others receive no economic help from the central government. This is a situation that can affect their economic sustainability in the long run and compromises the quality of the service. Indeed, many of the JASS examined could not afford buying chemicals to treat the water and so failed to implement the technical and sanitary protocols established in the legislation. As for the local governments, the regulatory reforms introduced in the 1990s prompted them to offer assistance to the JASS, for example through the Areas Tecnicas Municipales (ATM). Yet, as Table 4 shows, in 2015 only $13.5 \%$ of the JASS reported to have received technical support from the municipalities. Likewise, rural communities receive very little education regarding healthy habits, such as the importance of washing hands, adopting appropriate measures for storing water and installing bathrooms. These indicators suggest that the regulatory model adopted in Peru, while offering a solution for rural communities, still requires a greater involvement of public authorities.

\section{Fee schemes}

An essential aspect of the JASS is how they manage the service and set the fees. The members of the JASS have the right to use the water services and sit on the management or supervisory boards. In return, they are expected to pay a household fee established by the Assembly and participate in the maintenance works of the infrastructure such as the annual disinfection of the reservoirs. Each family is also responsible for maintaining its own indoor connection. Only in some cases, households can avoid communal works with the payments of an additional fee.

As it is to be expected, the ability of the JASS to raise fees is limited by the economic difficulties of their members. However, an advantage of these organizations is that their operating costs tend to be small, because households contribute with their work to maintain 
and run the water systems. Thus, the fees charged by the JASS tend to be lower than those set by public organizations, which in larger municipalities are regulated by SUNASS.

Still, a frequent problem of the JASS is the difficulty to charge households a fee that can recover the cost of the service. Table 5 shows that $25.1 \%$ of the JASS do not charge any fees, and those that do so only collect the $77.6 \%$ of the billed water. A close examination of the data reveals that there is a large percentage of the JASS that collects all the billed water, but there is also a relevant group of organizations with difficulties to enforce the payments.

The internal conflicts of the organizations might sometimes be the origin of their economic problems and can put at risk their sustainability. Indeed, when a part of the community disagrees with the decisions of the board and does not pay the fees, the JASS cannot appropriately maintain the infrastructure. For example, in 1997, the inhabitants of the municipality of El Ingenio (in the administrative region of Ica) left the JASS and created a users' association. The JASS was operating a water system financed by FONCODES and a Canadian cooperation agency, but the initial board did not receive the support of the local community and soon the service deteriorated due to payment defaults. After the creation of the new association and a change in management practices the system recovered successfully, even with the use of the initial fee scheme.

\section{Management of the systems}

As the JASS are more prevalent in communities where it is not possible to adopt another provision system and the population is relatively poor and lives in dispersed and remote areas, they cannot benefit from density economies and no cross subsidies from low to high cost areas can be established. Despite these difficulties, we saw on Table 3 that access to improved water in the communities served by the JASS is quite high and most households have indoor water connections. This result reflects the adequate management and design of the water systems run by many JASS, but also the support given by the PRONASAR and PNSR programs to rural communities.

Nowadays the JASS use guidelines that offer standardized solutions for the construction and maintenance of water systems and that consider the specific characteristics of each community. Most JASS obtain the water from springs, especially in the Sierra, whereas in the Coast and the Selva it is also very common to obtain the water from wells and rivers. Table 6 shows that $82.2 \%$ of the JASS use gravity systems to distribute the water, while $8.7 \%$ need to pump the water to the communities or use wells close to the households. According to the service regulations, the JASS are in charge of maintaining and disinfecting these systems, but $11 \%$ of them report they do not do so. On the other hand, half of the JASS have specialized employees that run the system and are paid according to the number of hours worked.

In order to design public policies that can enhance the service offered by the JASS it is essential to know how well they do in providing a quality service. For the sample of JASS in the survey, only half of them offer some type of treatment to the water. The population of rural communities has traditionally relied in the quality of the water they obtain from springs and many of them don't apply any purification treatment. However, the reservoirs and the distribution networks are frequently contaminated and this might be the origin of waterrelated diseases. Local governments are responsible for periodically testing the quality of the water offered by the JASS. However, in order to guarantee an adequate service other 
interventions should be offered by public institutions, for example, supervising the annual disinfection of the reservoirs and equipment, providing the products that would allow the chlorination of the water, and offering education to the population to adopt preventive actions such as boiling the water.

Another indicator to measure the quality of the service is the number of hours that the system is active during the day, which is 18.7 hours per day on average in our sample. The continuity of the service reduces the need to store water, which is another important channel for the propagation of water related diseases. The results show that many JASS deliver water 24 hours per day, but others have water shortages due to the lack of water in some periods of the year, the small capacity of the reservoirs, or the deficient functioning of the networks.

Our dataset does not allow us to directly measure another important aspect of the JASS, namely their economic and environmental sustainability. ${ }^{9}$ However, in recent years the Peruvian government and several international institutions have analyzed this question (WSP, 2007). Compared to earlier findings, these studies show an improvement in the economic sustainability and the maintenance of the water systems. Whittington et al. (2009) analyzed a group of rural communal organizations in Peru and concluded that many of them have succeeded in maintaining their system in acceptable working conditions. However, they note that most of the efforts of the JASS are devoted to repairing, rather than maintaining, the systems. The MVCS (2011) reported that only $30 \%$ of Peruvian systems were economically sustainable, $40 \%$ were in deficit and in the remaining $30 \%$ users did not pay for the service.ENDES (2011) argued that one of the reasons for the lack of sustainability of water systems is that less than $60 \%$ of them are managed by a JASS and only $14 \%$ of them have a member that has received some training to operate the system. Finally, we do not know of any study empirically comparing the performance and sustainability of public and communal water systems, which would give important insights for the design of the water policies adopted in the rural areas.

\section{CONCLUSIONS}

Communal water organizations are very prevalent across countries of Latin America where they constitute the default system of provision for poor, dispersed rural communities. In Peru, most of these organizations take the form of Juntas Administradoras de Servicios de Saneamiento (or JASS). After a process of administrative and political decentralization in the 1990s and 2000s, the Peruvian government transferred the responsibility for planning, constructing and operating water systems in rural areas to the JASS. Some years later it regulated many aspects that affect the operation of these organizations, such as the mechanism to elect the representatives, how they need to set the fees, or the design of the infrastructure. This process has meant the legal recognition of this provision system, one that had been informally used in the country for decades.

The goal of this paper is twofold. First, it empirically explores the main factors associated to the provision of water through a JASS. Second, it analyses some of the operational and governance aspects of the JASS that are key to their sustainability. On the first point, we show that the JASS are more likely in areas of strong Inca influence due to the presence of the Minka, a tradition of communal work that seems to foster the creation of JASS, and in more homogeneous communities from an ethnic and linguistic point of view. On the other hand, our empirical study shows that households are more likely to access water through a 
JASS in municipalities where local governments have fewer resources (both financial and technical) and where an important part of the population lives under the poverty line. This confirms the idea that the JASS are the default system in the rural and poor communities where local governments are unable to offer the service, while in richer municipalities their presence is much less frequent. Interestingly enough, in Peru the creation of the JASS has been promoted by the government and forms part of the country's strategy for universalizing the access to improved water. By contrast, in other countries this type of organization is the spontaneous response of the population to the lack of assistance by the state. Unfortunately, our dataset does not allow a direct comparison of public and communal provision systems. However, an important question for future research is whether communal organizations offers better answers to the specific problems of rural communities, and in which circumstances they should be maintained and enhanced.

Our analysis of the governance and operation of the JASS suggests that these communal organizations might be an important alternative to organize the provision of water services in rural areas of Peru. They offset the lack of financial and technical resources with the volunteer work provided by their members and their greater incentives to offer safe water. Moreover, their boards have better information about the problems affecting their water systems than the managers of public systems, usually located several hours away, might have. However, the consolidation of these institutions requires adequate regulation and supervision to ensure that water systems are correctly designed and managed, and that internal governance problems do not compromise their sustainability. Local self-regulation might sometimes suffer from a lack of democracy, accountability and fairness and for this reason the JASS might require the supervision of specialized agencies. The challenge for the future is to develop interventions that can enhance their performance, such as specialized training and technical assistance to maintain the infrastructures and to treat the water appropriately. On the other hand, in the coming years economic development may lead some rural communities to switch to alternative organizational forms to provide the water service, such as traditional public systems or communal systems supervised by the JASS and operated by specialized private firms. For example, a pilot program of the Water and Sanitation Program (WSP) was introduced in 2004 in 9 Peruvian municipalities to examine how rural communities can delegate the management of the service to private operators (WSP, 2007). Taking this into account, future research should analyze which provision regime is more adequate in each circumstance and which are the governance problems that these hybrid systems may pose. 


\section{REFERENCES}

Alesina, A. and E. La Ferrara (2000), Participation in Heterogenous Communities, Quarterly Journal of Economics, 115 (3), 847-904.

Alesina, A. and E. Zhuravskaya (2011), Segregation and the Quality of Government in a Cross section of Countries, American Economic Review, 101 (5): 192-1911.

Alford, J. (2014), The multiple facets of co-production: Building on the work of Elinor Ostrom. Public Management Review 16 (3): 299-316.

Bakalian, A. and W. Wakeman (2009), Post-Construction Support and Sustainabiilty in Community-Managed Rural Water Supply, World Bank- Netherlands Water Partnership, Water Sector Board Discussion Paper Series, 48731.

Banerjee, A. and R. Somanathan (2007), The political Economy of public goods: some evidence from India, Journal of Development Economics, 82 (2), 287-214.

Bardhan, P. (1993). Analytics of the institutions of informal cooperation in rural development. World Development, 21(4), 633-639.

Brandsen, T. and J.K. Helderman (2012), The Trade-Off Between Capital and Community: The Conditions for Successful Co-production in Housing, Voluntas, 23 (4), 1139-115.

Calderón J. (2004), Agua y Saneamiento: El Caso del Perú Rural. mimeo.

Castillo, O. and Vera, R. (1998), Descentralización, gobierno local y saneamiento básico rural. Estudio de caso en el Perú. PAS BM, PNUD, Lima.

Clarke, G., K. Kosec and S. Wallsten (2009), Has private participation in water and sewerage improved coverage? Empirical Evidence from Latin America, Journal of International Development, 21, 327-361.

Dasgupta, A. and V. Beard (2007), Community Driven Development, Collective Action and Elite Capture in Indonesia, Development and change, 38(2), 229-249.

ENDES (2011), Encuesta demográfica y de salud familiar. Instituto Nacional de Estadística e Informática and OCF International.

Engel, E., R. Fischer, and A. Galetovic (2013), The basic public finance of public-private partnerships, Journal of the European Economic Association 11 (1), 83-111.

Espinoza, W. (1997), Los Incas: Economia, Sociedad y Estado en la Era de Tahuantinsuyo, AMARU Editores, Lima.

Felgendreher, S., and P. Lehmann (2016), Public Choice and Urban Water Tariffs- Analytical Framework and Evidence from Peru, Journal of Environment \& Development, Vol. 25(1) 73-99. 
Galiani, S., M. Gonzalez-Rozada and E. Schargrodsky (2009), Water Expansions in Shantytowns: Health and Saving, Economica, 76, 607-622.

Gassner, K., A. Popov and N. Pushak (2008), Does Private Sector Participation Improve Performance in Electricity and Water Distribution? Trends and Policy Options, 6, World Bank, PPIAF, Washington D.C.

Gorton, (2009), M., J. Sauer, M. Peshevski, D., Bosev, and D. Shekerinov (2009), Water Communities in the Republic of Macedonia: An Empirical Analysis of Membership Satisfaction and Payment Behavior, World Development, 37 (12), 1951-1963.

Hailu, D., Guerreiro Osorio, R., and Tsukada, R. (2012), Privatization and renationalization: what went wrong in Bolivia's water sector? World Development, 40(12), 2564--2577.

Hansen,M. T. Faran, and D. O'Byrne (2015), The Best Laid Plans: Using the Capability Approach to Assess Neoliberal Conservation in South Africa-The Case of the iSimangaliso Wetland Park, 24: 395-417.

Hart, O. (2003), Incomplete contracts and public ownership: Remarks, and an application to public-private partnerships, The Economic Journal 113 (486), 69-76.

Harvey, P. A. and R. A. Reed (2006), Community-managed water supplies in Africa: Sustainable or dispensable?, Community Development Journal, 42 (3), 365-378.

Iossa, E. and D. Martimort (2012), Risk allocation and the costs and benefits of publicprivate partnerships, RAND Journal of Economics 43 (3), 442-474.

Israel, D. (2007), Impact of increased access and price on household water use in Urban Bolivia. Journal of Environment and Development, 16, 58-83.

Joshi, A. and M. Moore (2004), Institutional Co-production: Unorthodox Public Service Delivery in Challeging Environments, The Journal of Development Studies, Vol. 40, 31-49.

Katz, T. and J. Sara (1997), Making rural water supply sustainable: recommendations from a global study. Water and Sanitation Program, Washington, D.C.

Llano-Arias, V. (2015), Community Knowedge Sharing and Co-Production of Water Services: Two Cases of Community Aqueduct Associations in Colombia, Water Alternatives, 8 (2), 77-98.

Lockwood, H., Bakalian, A., and W. Wakeman (2003) Assessing sustainability in rural water supply: The role of follow-up support to communities. Literature review and desk review of rural water supply and sanitation project documents. Washington, DC: World Bank.

Mansuri, G and Rao, V. (2004), Community-Based and -Driven Development: A Critical Review, The World Bank Research Observer, 19 (1), pp. 1-39. 
Mckenzie, D. and D. Mookherjee (2003), The distribution impact of privatization in Latin America: evidence from four countries, Economia, 3 (2), 161-233.

McMillan, R., Spronk, S., and Caswell, C. (2014), Popular participation, equity, and coproduction of water and sanitation services in Caracas, Venezuela. Water International, 39(2), 201-215.

Meinzen-Dick, R. (2007). Beyond panaceas in water institutions. PNAS, 104 (39), 1520015205 .

Miguel, E. Gugerty, M.K. (2005), Ethnic diversity, social sanctions and public goods in Kenya, Journal of Public Economics, 89 (11-12), 2323-2368.

MIDIS (2012), Mapa de Vulnerabilidad a la Inseguridad Alimentaria, 2012. Ministerio de Desarrollo e Inclusion Social, Peru.

Moriarty, P., S. Smits, J. Butterworth, and R. Franceys (2013) Trends in rural water supply: Towards a service delivery approach, Water Alternatives 6(3), 329-349.

MVCS (2011), Construcción y Saneamiento. Manual de Operaciones: Programa Nacional de Agua y Saneamiento Rural PRONASAR 2011-2013.

Newbery, D. M. (2000), Privatization, Restructuring and Regulation of Network Utilities . The Walras-Pareto Lectures, Cambridge, MA: The MIT Press.

Olson, M. (1965), The Logic of Collective Action: Public Goods and the Theory of Groups. Cambridge Mass. Harvard University Press.

Ostrom, E. (1990), Governing the commons: The evolution of institutions for collective action. New York: Cambridge University Press.

Ostrom, E. (1996), Crossing the Great Divide: Coproduction, Synergy, and Development, World Development, Vol. 24 (6), 1073-1087.

Ostrom, E. (2004), Understanding collective action, In Meinzen-Dick R. and M. Di Gregorio (eds.) Collective Action and Property Rights for Sustainable Development. 2020 vision for food, agriculture and the environment. Focus 11, IFPRI, International Food Policy Research Institute, Washington.

Palmer, C. (2014) Making a Difference? Accounting for Nongovernmental Organizations in the Comanagement of Lore Lindu National Park, Indonesia, The Journal of Environment \& Development, 23: 417-445.

Pestoff, V. (2006), Citizens as co-producers of welfare services: Preschool services in eight European countries. Public Management Review, 8 (4), 03-520.

Platteau, J.P. (2004), Monitoring Elite Capture in Community-Driven Development', Development and Change, 35(2), 223-46. 
Prokopy, L.S. and Thorsten, R. (2008), The role of wealth, income, and social capital in determining a household's choice to participate in rural water-supply projects in Peru. Environment and Planning C: Government and Policy, 26, 1162- 1176.

PROTOS-CEDIR (2011), Yakukamay. Alianza público-comunitarias: un modelo de gestión desde el CENAGRAP. Administradoras de Agua Potable de Cañar.

Rigon, A. (2014), Building Local Governance: Participation and Elite Capture in Slumupgrading in Nenya, Development and Change, Volume 45 (2): 257-283.

Ringskog, K., Yepes, G., and Vasques, R. (2007). Evaluación de los operadores locales de pequeña escala de agua y saneamiento en el Peru. Lima, Peru: Ministerio de Vivienda, Construcción y Saneamiento, Water and Sanitation Program, World Bank.

Rosentraub, M. S., and Sharp, E. B. (1981), Consumers as producers of social services: Coproduction and the level of social services. Southern Review of Public Administration, 502-539.

Sicilia, M., A. Sancino, M. Andreani, R. Ruffini (2015), Public services management and coproduction in multi-level governance settings, International Review of Administrative Sciences, 0 (0), 1-20.

Schweitzer, R., C. Grayson, and H. Lockwood (2014) Mapping of Water, Sanitation, and Hygiene Sustainability Tools, Triple-S Working Paper 10.

Shrestha, M. (2013) Internal versus External Social Capital and the Success of Community Initiatives: A Case of Self-Organizing Collaborative Governance in Nepal, Public Administration Review, Vol. 72 (1), 154-164.

Smits, S., Tamayo, S. P., Ibarra, V., Rojas, J. Benavidez, A. and Bey, V (2012), Gobernanza y sostenibilidad de los sistemas de agua potable y saneamiento rurales en Colombia. Monografia No. IDB-MG-133. Washington, D.C., Banco Interamericano de Desarrollo.

Tafon, R. and F. P. Saunders (2015) Power Relations and Cassava: Conservation and Development in Cameroon, The Journal of Environment \& Development, 24: 82-104.

Tan, J. (2012), The Pitfalls of Water Privatization: Failure and Reform in Malaysia, World Development, Volume 40 (12), 2552--2563.

Tirole, J. (1988), The Theory of Industrial Organization. Cambridge, MA: The MIT Press.

Viscusi, W. K., J. M. Vernon, and J. E. Harrington (2000), Economics of Regulation and Antitrust. Cambridge, MA: The MIT Press.

Whittington, D., Davis, J., and McClelland, E. (1998), Implementing a demand-driven approach to community water supply planning: A case study of Lugazi, Uganda. Water International, 23(3), 134-145. 
Whittington, D., J. Davis, L. Prokopy K. Komives, R. Thorsten, H. Lukacs, A. Balalian, and W. Wakeman (2009), How well is the demand-driven, community management model for rural supply systems doing? Evidence from Bolivia, Peru and Ghana, Water Policy, 11, 696718.

WSP (2007), Memoria del taller PRONASAR-PPPL. Servicios sostenibles con nuevos modelos de gestión para las pequeñas ciudades del Perú. Water and Sanitation Program.

WSP (2008), Operadores locales de pequeña escala en América Latina. Su participación en la prestación de los servicios de agua y saneamiento. Water and Sanitation Program. 
Table 1. Descriptive statis tics

\begin{tabular}{lcrrrr}
\hline \hline & Observations & Mean & Std. Dev. & Min & Max \\
\hline \hline Communal provision & $\mathbf{2 2 2 2 8}$ & 0.423 & 0.494 & 0 & 1 \\
Population & $\mathbf{3 2 9 3 8}$ & 76151.5 & 130100.2 & 185.0 & 962554.0 \\
Revenues Municipality PC & $\mathbf{3 2 6 6 5}$ & 3938472.0 & 6106733.0 & 69005.0 & 7770086.0 \\
Professional Employees PC & $\mathbf{3 2 9 0 7}$ & 0.003 & 0.003 & 0 & 0.067 \\
Poverty Index & $\mathbf{3 2 9 3 8}$ & 395965.0 & 250764.0 & 0.1 & 97.800 \\
Altitude & $\mathbf{3 2 1 0 3}$ & 1607.0 & 1514.0 & 0.003 & 4645.0 \\
Queshua & $\mathbf{3 2 9 6 1}$ & 0.185 & 0.284 & 0 & 0.998 \\
Inca & $\mathbf{3 0 2 3 7}$ & 0.859 & 0.347 & 0 & 1 \\
Cabildo & $\mathbf{3 3 0 2 3}$ & 0.623 & 0.485 & & \\
Language Concentration & $\mathbf{3 2 9 6 1}$ & 0.818 & 0.169 & 0.351 & 1 \\
\hline \hline
\end{tabular}


Table 2. Factors explaining the presence of the JASS (Probit Estimations - Marginal effects)

\begin{tabular}{|c|c|c|c|c|c|c|c|}
\hline \multirow{2}{*}{$\begin{array}{l}\text { Dependent variable } \\
\text { Communal provision } \\
\end{array}$} & \multirow[b]{2}{*}{ I } & \multirow[b]{2}{*}{ II } & \multicolumn{3}{|c|}{ Specifications } & \multirow[b]{2}{*}{ VI } & \multirow[b]{2}{*}{ VII } \\
\hline & & & II & IV & $\mathbf{v}$ & & \\
\hline Log Population & $\begin{array}{c}'-\mathbf{- 0 . 1 0 9 0} \text { ***** } \\
(0.0159)\end{array}$ & $\begin{array}{l}-\mathbf{- 0 . 1 0 1 8} \text { **** } \\
(0.0163)\end{array}$ & $\begin{array}{c}-\mathbf{- 0 . 1 3 1 4} * * * \\
(0.0156)\end{array}$ & $\begin{array}{c}-\mathbf{- 0 . 0 9 9 6 * * *} \\
(0.0164)\end{array}$ & $\begin{array}{c}-\mathbf{- 0 . 0 6 4 7 * * * *} \\
(0.0173)\end{array}$ & $\begin{array}{c}-\mathbf{- 0 . 0 6 4 7 * * * *} \\
(0.0171)\end{array}$ & $\begin{array}{c}-\mathbf{0 . 0 8 0 7} * * * * \\
(0.0187)\end{array}$ \\
\hline Local Government Revenies PC & $\begin{array}{c}\mathbf{0 . 0 4 0 3} \\
0.0353\end{array}$ & & & & & & \\
\hline Professional Employees PC & $\begin{array}{c}\mathbf{- 2 1 . 2 3 0 1 * *} \\
(10.2389)\end{array}$ & $\begin{array}{c}\mathbf{- 1 3 . 5 0 9 2} \\
(9.0443)\end{array}$ & $\begin{array}{l}-20.2511 \\
(8.7917)\end{array}$ & $\begin{array}{c}-\mathbf{1 2 . 3 4 0 6 * * *} \\
(8.8482)\end{array}$ & $\begin{array}{l}\mathbf{- 1 0 . 2 2 9} \\
(8.8751)\end{array}$ & $\begin{array}{l}\mathbf{- 1 0 . 2 4 1} \\
(8.8567)\end{array}$ & $\begin{array}{c}\mathbf{- 1 0 . 1 4 3 8} \\
(8.4742)\end{array}$ \\
\hline Poverty Index & $\begin{array}{l}\mathbf{0 . 0 0 5 9} * * * \\
(0.0011)\end{array}$ & $\begin{array}{l}\mathbf{0 . 0 0 5 5} * * * \\
(0.0012)\end{array}$ & & $\begin{array}{c}\mathbf{0 . 0 0 5 8} * * * \\
(0.0012)\end{array}$ & $\begin{array}{l}\mathbf{0 . 0 0 2 1}^{*} \\
(0.0012)\end{array}$ & $\begin{array}{l}\mathbf{0 . 0 0 2 1} * \\
(0.0012)\end{array}$ & $\begin{array}{l}\mathbf{0 . 0 0 2 2} * \\
(0.0012)\end{array}$ \\
\hline Altitude & $\begin{array}{c}\mathbf{0 . 0 2 0 3} \\
(0.0227)\end{array}$ & $\begin{array}{l}\mathbf{0 . 0 1 1 6} \\
(0.0223)\end{array}$ & $\begin{array}{l}\mathbf{0 . 0 1 9 6} \\
(0.0228)\end{array}$ & $\begin{array}{r}\mathbf{0 . 1 3 7 4} \\
(0.0233)\end{array}$ & $\begin{array}{l}-\mathbf{- 0 . 0 1 1 4} \\
(0.0232)\end{array}$ & $\begin{array}{r}-\mathbf{0 . 0 1 1 3} \\
(0.0230)\end{array}$ & $\begin{array}{c}-\mathbf{- 0 . 0 0 8 0} * * \\
(0.0232)\end{array}$ \\
\hline Queshua & & $\begin{array}{l}\text { 0.2391** } \\
(0.1242)\end{array}$ & $\begin{array}{c}\mathbf{0 . 3 9 9 4} * * * \\
(0.1224)\end{array}$ & $\begin{array}{c}\mathbf{0 . 2 5 4 6} * * \\
(0.1351)\end{array}$ & $\begin{array}{l}\mathbf{0 . 0 0 4 1} \\
(0.1311)\end{array}$ & & \\
\hline Inca & & $-0.3302 * * *$ & $-0.2719 * * *$ & $-0.3394 * * *$ & $-0.3658 * * *$ & $-0.3660 * * *$ & $-.3675 * * *$ \\
\hline Cabildo & & $\begin{array}{l}(0.0651) \\
\mathbf{- 0 . 1 4 1 7} \\
(0.0340)\end{array}$ & $\begin{array}{c}(0.0739) \\
\mathbf{0 . 0 0 8 4} \\
(0.0345)\end{array}$ & $\begin{array}{l}(0.0657) \\
\mathbf{- 0 . 0 1 3 5}\end{array}$ & $\begin{array}{c}(0.0469) \\
\mathbf{- 0 . 0 3 6 5} \\
(06962)\end{array}$ & $\begin{array}{l}(0.0464) \\
\mathbf{0 . 3 5 8 9}\end{array}$ & $\begin{array}{l}(0.0472) \\
-\mathbf{0 . 0 4 4 1}\end{array}$ \\
\hline Language Concentration & & & & $\begin{array}{l}\mathbf{0 . 2 7 1 3} \\
(0.1931)\end{array}$ & $\begin{array}{l}\mathbf{0 . 3 5 9 5 *} \\
(0.5814)\end{array}$ & $\begin{array}{l}0.3589 * \\
(0.3589)\end{array}$ & $\begin{array}{c}\mathbf{0 . 4 2 4 0} \text { *** } \\
(0.1916)\end{array}$ \\
\hline Region FE & Yes & Yes & Yes & Yes & Yes & Yes & Yes \\
\hline House holds controls & No & No & No & No & Yes & Yes & Yes \\
\hline Pseudo R2 & 0.1962 & 0.2015 & 0.1913 & 0.287 & 0.2991 & 0.2991 & 0.312 \\
\hline Test joint sign & $307.05^{* * * *}$ & $313.26^{* * * *}$ & $301.18^{* * * * *}$ & $299.32 * * *$ & $1021.88^{* * * *}$ & $1014.14 * * *$ & $1111.28^{* * * *}$ \\
\hline Number of observations & 21626 & 21729 & 21729 & 21729 & 15927 & 15927 & 15645 \\
\hline
\end{tabular}

Number of observations $21626 \quad 21729$

clustered at the municipality level). Statistical significance at $1 \%(* *), 5 \%(* *), 10 \%(*)$. Source: ENDES survey 
Table 3: Characteristics of the rural communities attended by the JASS

\begin{tabular}{|c|c|c|c|c|c|}
\hline & All JASS & Costa & Sierra & Selva & Lima \\
\hline Average population of the rural community & 428.9 & 380.6 & 450.0 & 480.6 & 453.0 \\
\hline Average number of households & 115.6 & 99.9 & 121.5 & 110.5 & 171.5 \\
\hline Average number of households with improved water & 81.5 & 79.8 & 80.0 & 86.0 & 118.3 \\
\hline Average number of households with sewerage & 53.9 & 50.2 & 55.36 & 46.9 & 74.7 \\
\hline Average coverage of improved water $(\%)$ & 70.5 & 79.8 & 65.8 & 70.8 & 68.9 \\
\hline Average coverage of sewerage $(\%)$ & 46.6 & 50.2 & 45.5 & 42.4 & 43.5 \\
\hline Main ethnic group in the community is Aymara $(\%)$ & 1.9 & 0.1 & 3.2 & 0.0 & 0.0 \\
\hline Main ethnic group in the community is Quechua $(\%)$ & 35.0 & 14.8 & 51.4 & 0.0 & 0.2 \\
\hline Number of rural communities & 10067 & 3342 & 5904 & 468 & 355 \\
\hline
\end{tabular}

Source: PNSR survey 
Table 4: Characteristics of the JASS

\begin{tabular}{|c|c|c|c|c|c|}
\hline & All JASS & Costa & Sierra & Selva & Lima \\
\hline Registered in the local government (\%) & 49.6 & 54.3 & 49.7 & 32.3 & 50.1 \\
\hline Last election of the Board after $2013(\%)$ & 90.9 & 88.9 & 91.8 & 90.7 & 93.6 \\
\hline All board members appointed $(\%)$ & 78.8 & 80.7 & 78.5 & 75.7 & 73.6 \\
\hline Average number of women in the board & 0.62 & 0.63 & 0.64 & 0.51 & 0.61 \\
\hline Board without any women (\%) & 56.3 & 56.1 & 54.8 & 64.8 & 60.0 \\
\hline Average number of meetings of the board (last 6 months) & 3.1 & 2.7 & 3.4 & 3.0 & 3.4 \\
\hline Boards that have not meet in the last 6 months $(\%)$ & 19.8 & 21.4 & 19.2 & 18.0 & 17.7 \\
\hline Technical support of the local government $(\%)$ & 13.5 & 6.4 & 19.9 & 3.2 & 2.0 \\
\hline Has a bank account (\%) & 14.9 & 20.2 & 9.8 & 23.2 & 33.2 \\
\hline Carriers accounting records $(\%)$ & 37.3 & 38.3 & 32.9 & 50.7 & 64.7 \\
\hline Reports results to the assembly (\%) & 26.3 & 28.2 & 21.7 & 38.9 & 50.4 \\
\hline $\begin{array}{l}\text { Promotes hygiene and environmental sanitation practices } \\
\text { (courses, campaigns, etc.) }(\%)\end{array}$ & 9.7 & 5.3 & 11.3 & 18.0 & 4.2 \\
\hline Number of JASS & 10703 & 3445 & 5930 & 973 & 355 \\
\hline
\end{tabular}

Source: PNSR survey 
Table 5: Tariff schedule and revenues

\begin{tabular}{lccccc}
\hline \hline & All JASS & Costa & Sierra & Selva & Lima \\
\hline \hline Metered tariff (\%) & 3.7 & 6.9 & 0.6 & 8.2 & 4.4 \\
The JASS doesn't bill the water (\%) & 25.1 & 25.7 & 21.0 & 40.1 & 35.5 \\
Average monthly tariff (soles per m3) & 2.7 & 3.7 & 1.5 & 5.3 & 4.1 \\
Average monthly billing (soles) & 450.5 & 636.3 & 209.1 & 724.3 & 909.2 \\
Average monthly revenues (soles) & 349.6 & 479.9 & 162.6 & 567.0 & 768.3 \\
Bill collection (\%) & 77.6 & 75.4 & 77.7 & 78.3 & 84.5 \\
Average number households up to date in the payments & 97.8 & 103.0 & 88.4 & 103.2 & 132.3 \\
\hline Number of JASS & & & & & \\
\end{tabular}

Note: For the construction of this table we only considered the JASS that have accounting records. Source: PNSR survey 
Table 6: Characteristics of the water systems managed by the JASS

\begin{tabular}{|c|c|c|c|c|c|}
\hline & All JASS & 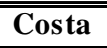 & Sierra & 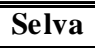 & 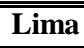 \\
\hline Age of the systems (years) 1 & 14.5 & 14.6 & 14.8 & 12.8 & 12.7 \\
\hline \multicolumn{6}{|l|}{ Water system $(\%)$ : } \\
\hline 1. Pumping aqueduct & 8.7 & 15.6 & 3.2 & 13.8 & 26.3 \\
\hline 2. Gravity aqueduct & 82.2 & 75.2 & 90.9 & 51.7 & 71.6 \\
\hline 3. Water well & 8.9 & 9.0 & 5.8 & 34.3 & 1.9 \\
\hline \multicolumn{6}{|l|}{ Water treatment $(\%)$ : } \\
\hline 1. Water chlorination & 47.4 & 35.2 & 56.7 & 29.3 & 42.2 \\
\hline 2. Water filtration & 2.0 & 1.4 & 1.4 & 5.3 & 8.4 \\
\hline Provides system maintenance $(\%)$ & 88.4 & 86.6 & 89.8 & 91.8 & 73.8 \\
\hline Has technical employees (\%) & 51.2 & 44.3 & 54.7 & 65.1 & 23.3 \\
\hline Has a technical protocol to run the service $(\%)$ & 52.1 & 48.8 & 53.2 & 53.6 & 62.8 \\
\hline Hours of service per day 2 & 18.7 & 16.7 & 20.3 & 19.3 & 18.6 \\
\hline Number of JASS & 10677 & 3477 & 6072 & 815 & 353 \\
\hline
\end{tabular}

Note: 1 . Some JASS have not reported this information

2. Calculations made with a reduced number of observations due to information restrictions

Source: PNSR survey 


\section{NOTES}

${ }^{1}$ WHO/UNICEF Joint Monitoring Programme for Water Supply, Sanitation and Hygiene.

${ }^{2}$ The industrial organization and regulation literatures have analyzed the traditional mechanisms for the provision of public goods: public, private and regulated monopolies (Tirole 1988; Newbery 2000; Viscusi, Vernon, and Harrington 2000). There is also a growing literature on public-private partnerships, examining several problems of this provision system such as incomplete contracts, incentive schemes and renegotiation costs (Engel, Fischer, and Galetovic, 2013; Hart, 2003; and Iossa and Martimort 2012).

3 The literature has identified several dimensions related to the sustainability of water systems, including environmental, institutional, administrative, economic, technical and social. For a review of the various concepts of sustainability in rural water systems see for example Lockwood et al. (2003), Harvery and Reed (2006) and Moriarty et al. (2013).

${ }^{4}$ Ostrom (1996) defines co-production as the "process through which inputs used to produce a good or service are contributed to by individuals who are not in the same organization".

${ }^{5}$ Peruvian municipalities are divided in smaller administrative units known as population units (centros poblados) and these are classified as urban or rural attending mainly to a population criterion. The Plan National de Saneamiento 2006-2015 defines rural units as those with less than 2,000 inhabitants and that do not serve as capital of the municipality. There are 734 urban units that concentrate around $70 \%$ of the population while the rest live in 85,138 rural units across the country.

${ }^{6}$ Given that the dependent variable is defined at the household level while most of the explanatory variables are at the municipality level, standard errors are clustered at the municipality level to allow for correlation among observations within municipalities.

${ }^{7}$ This poverty index is computed taking into account the access to basic services such as water, but not the type of provision of the water service. Thus, conditional on having access to water, the poverty index is a valid explanatory variable for the probability that such access takes place through a JASS.

${ }^{8}$ The statistical insignificance of the coefficient on the proportion of Quechuas is not surprising given that we include an individual control on ethnicity that might capture much of the effect of Quechuas.

${ }^{9}$ There are several definitions of sustainability for water systems. For a discussion about the possible metrics see Lockwood et al. (2003) and Schweitzer et al. (2014). 